\title{
LIFE AFTER A FESTIVAL: LOCAL LEADERSHIP AND THE LASTING LEGACY OF FESTIVALS
}

\author{
AMANDA DAVIES \\ School of Built Environment, Curtin University, Perth, Australia
}

\begin{abstract}
This article considers how local leadership capacities can be developed through locally organized festivals and argues that this skill development can be an important legacy of festivals. It draws on the case study of SnowFest, a festival held annually from 2000 to 2003 in a small rural town in New South Wales, Australia. It is argued that festivals provide a useful setting for the development of local leadership capacities. Through reviewing the events leading up to and following SnowFest it was found that seven followers learned new leadership skills through their involvement in SnowFest. Four of these followers had since moved into leadership roles in the community. The particular nature of the leadership of the SnowFest leaders was important in enabling followers to develop their own leadership skills. The article contributes to the growing body of scholarly work that argues the impacts and benefits of locally organized festivals can extend beyond the spatial and temporal limits of the festival event and therefore beyond the scope of typical evaluation tools. The findings of this study are particularly relevant to small rural communities that are negotiating major socioeconomic changes, where effective local leadership has been identified as being crucial to the success of bottom-up community adaptation initiatives.
\end{abstract}

Key words: Transactional leadership; Transformational leadership; Legacy; Local leadership; Rural festivals; Rural development

\section{Introduction}

Over the last four decades, there has been a proliferation of research examining the impacts of festivals for host communities and participants (Carlsen, Ali-Knight, \& Robertson, 2011; Connell \& Gibson, 2011; Formica, 1998; Getz, 2000). This research has distinguished between commercial events that are organized with limited input from the host community and also those that are organized largely by volunteers within the host community. Although much of this work has focused on recording the economic impacts of festivals, a robust body of work has directed attention to the broader and less tangible sociocultural impacts. This article seeks to build on this body of work to expand knowledge about how locally organized festivals can act as vehicles for the development of 
local leadership capacities. By doing so, this article argues that festivals have an important role in generating lasting legacies for host communities that extend well beyond the duration of a festival.

The article draws on the case study of SnowFest, a festival that was held annually in a small rural Australian town in the agricultural heartland of New South Wales, Australia, between 2000 and 2003, and was targeted at enhancing the socioeconomic viability of the town. The role of SnowFest in the development of leadership capacities within the town from July 2000 to June 2014 is reviewed.

Given the focus of this study on locally organized festivals, the following section summarizes the core findings of studies that are also focused on locally organized festivals and events. The major thematic developments in the body of work that considers the legacy of festivals are also reported. Despite the significant achievements of research examining the broad impacts of festivals, it is argued that research attention given to understanding the role of festivals in community leadership development has been limited. Following the review of the festival literature, a review of scholarship on local community leadership is presented. This review focuses on rural communities and examines the usefulness of the Transformational-Transactional Leadership model for understanding the operation of leadership within locally organized festivals and events.

The second half of the article presents an analysis of the development of local leadership capacities during SnowFest. Section three sets out the study's methods and section four documents how leadership skills were developed through SnowFest. The final section of the article argues that SnowFest created an important space for the members of the organizing committee to develop and enhance their leadership capacities. It is argued that the transference of leadership skills from the SnowFest leaders to committee members is an important legacy of SnowFest.

\section{Beyond Economic Impacts of Festivals}

Within the scholarship on festivals and events there has been an enduring effort directed towards understanding and modeling the economic impacts of festivals and events (Robertson, Rogers, \&
Leask, 2009). Through addressing large-scale and small-scale events, globally focused and localized events, one off and reoccurring events, this economically focused literature has set the foundation for festival studies. Expanding on this foundation, scholars of festival studies have directed their attention toward the noneconomic impacts of festivals (Mair \& Whitford, 2013). This contextually diverse and theoretically broad body of scholarship has substantially advanced knowledge about the role of festivals in promoting the social and economic viability and culture of places (Arcodia \& Whitford, 2006; Connell \& Gibson, 2011; Crespi-Vallbona \& Richards, 2007; Moscardo, 2007; Robertson et al., 2009; Van Winkle \& Woosnam, 2014). Indeed, it is noted that this journal published a double special issue (Volume 11, Issue 1 and 2) titled "Festival and Events: Beyond Economic Impacts.” The articles of the double special issue highlight the major contributions of the scholarship on the impacts of festivals that extend beyond economic concerns (Carlsen et al., 2011). This article contributes to further extending knowledge about the impacts of festivals by examining how festivals can act as sites for the development of local leadership capacities.

Following a structured review of the peerreviewed literature on festival and event management, Getz, Andersson, and Carlsen (2010) argued that the role and nature of leadership required for the organization of festivals had rarely been explicitly studied. Of those studies that specifically considered leadership, the dominant approach was to document the roles, responsibilities, and actions of individuals in senior management or directorship positions over the period leading up to and of the festival (e.g., see, Carlsen, Andersson, Ali-Knight, Jeager, \& Taylor, 2010; Caust, 2002; Hede \& Rentschler, 2007; Larson, 2011). Although those studies generated valuable information about how the actions of the individual leader (or management team) could impact the running and success of festivals, little attention was given to examining the impacts of their leadership beyond the temporal and spatial limits of the festival.

Insight into the potential impact of festival leadership can be gained through an examination of studies that assess the broader social and cultural implications of festivals themselves (Arcodia \& Whitford, 
2006; Connell \& Gibson, 2011; Gibson, Connell, Waitt, \& Walmsley, 2011; Rollins \& Delamere, 2007; Sharp, 2008; Small, Edwards, \& Sheridan, 2005). Haven-Tang and Jones (2012) argued that locally organized festivals could facilitate the generation of new social and economic networks and behaviors, with the role of the local organizers critical to this. Festivals provided opportunities for the development and maintenance of shared narratives of belonging through facilitating participation in shared activities or experiences, including the organization of the festival itself (Darian-Smith, 2011). Festivals also have a role in bringing together geographically disperse communities of people who share similar interests-again not just in regard to festival attendance but also in respect to organizing an event (Darian-Smith, 2011). Festivals and the nature in which they are organized, therefore, have a role in coalescing community resources to promote positive social outcomes.

While many festivals and events are focused on generating short-term, nonpermanent activities (impact), others specifically seek to generate longer-term and often less tangible outcomes such as new identities for localities, enhanced social capital, and improved community well-being (legacy) (Harris, 2014; Preuss, 2007; Wood, 2006). As the scholarship documenting the impacts of festivals has broadened beyond the economic impacts of festivals, a similar broadening of scope has occurred in the scholarship documenting the legacy of festivals and events (Bob \& Swart, 2010; Li \& McCabe, 2013). Within the work on festival and event legacy, scholars have considered the positive and negative and planned and unplanned legacies of events and festivals. Preuss (2007) defined legacy as "irrespective of the time of production and space, legacy is all planned and unplanned, positive and negative, tangible and intangible structures created for and by [an] event that remain longer than the event itself” (p. 211). A legacy is that which:

1. Remains longer than an impact and can be long or short in duration.

2. Develops new opportunities out of an initial impact, and with time as the environment changes may obtain its own dynamic.

3. Can be cause indirectly by the event impact.
4. Can be both positive and negative and tangible and intangible.

5. Can operate at the individual, local, international, or global scale (Preuss, 2014).

Preuss' (2007, 2014) definition, while comprehensive, does present difficulties when it comes to identifying, measuring, or evaluating the legacy of events. For the purpose of identifying and measuring legacy, Preuss proposed that events could generate "hard" and "soft" event structures. "When event-structures change the location factors (supply side) in a city, any activity based on these changes is the event legacy” (Preuss, 2007, p. 208). Soft structures can include organizational frameworks, technological knowledge, social and political networks, and cultural goods, including cultural identity and common memory. Hard structures can include infrastructure such as buildings, roads, and telecommunications, as well as cultural attractions. While hard structures are relatively easy to identify, soft structures including the "intangible effects such as community pride and social cohesion are more difficult to assess” (Bob \& Swart, 2010, p. 78; Gibson et al., 2011).

Given the complexity of identifying the legacy of events and festivals, particularly those associated with soft structures, researchers have made considerable progress by focusing studies on examining just one or two soft structures and tracing development of these over a defined period of time and within defined geographic parameters. Berridge (2012), for example, in a review of the 2007 Tour de France event in London, explored the enhancement of place image as an event legacy; similarly Clifton, O’Sullivan, and Pickernell (2012) examined the impact of the Cardiff centenary celebrations. Extending on these themes, Mackeller (2013) considered the impact of a World Rally Championship event to the place image of an Australian rural town, with consideration also given to the negative and positive impacts on community social capital. Duffy and Waitt (2011) gave attention to the role of festivals in influencing processes of belonging to place and Begg (2011) considered the role of folk festivals in generating and facilitating the performance of distinct subcultures. The SnowFest case study follows the same approach as these studies 
in that it focuses on a particular soft structurethe role and nature of leadership. In doing so, the implications for leadership development within the host community associated with the SnowFest case are identified.

\section{Local Leadership and Rural Community Socioeconomic Well-Being}

Since the mid-1990s, strategies for rural development in advanced industrial countries have been based on notions of self-help and have sought to foster bottom-up community initiatives (HerbertCheshire, 2000). Developing the local leadership capacities of rural residents was identified as crucial to the success of bottom-up community development and adaptation initiatives (Sorensen \& Epps, 1996), and from the mid-1990s there was a proliferation of leadership training programs introduced across the contextually diverse rural settings of advanced industrial countries (Madsen \& O’Mullan, 2014; also see Beer, 2014).

Studies of local leadership have investigated the “traits” typical to leaders (Fiol, Harris, \& House, 1999; Levay, 2010). Kirkpatrick and Locke (1991) concluded that across the literature on leadership compelling evidence existed to support the notion that leaders possess certain traits, and that followers or "nonleaders" do not have these. Leader traits include drive (a broad term that includes achievement, motivation, ambition, energy, tenacity, and initiative); leadership motivation (the desire to lead but not to seek power as an end in itself); honesty and integrity; self-confidence (which is associated with emotional stability); cognitive ability; and knowledge of business (Kirkpatrick \& Locke, 1991; Zaccaro, Kemp, \& Bader, 2004). A substantial volume of research has been published on leader traits (Judge, Piccolo, \& Kosalka, 2009), and of particular relevance to the current study, Sorensen and Epps' (1996) examination of local leaders in rural Australian communities concluded that although leaders had similar traits, the situational context was paramount to leadership effectiveness. They concluded, therefore, it was not possible to develop a definitive list of traits that could define an "effective" local leader.

Moving beyond a focus on leader traits, scholars have examined the relationship between leaders and followers, considering the traits of the follower and the situational context in which the leadership is developed. In their examination of local leaders in rural Australia, Onyx and Leonard (2011) argued that although leaders personality and "traits" were important, to successfully undertake community development initiatives leaders needed to engage the support of the broader community. Engaging this support required the followers to have particular traits and knowledge. This finding aligns with studies that examine follower traits in formal employment arrangements (Campbell, Ward, Sonnenfeld, \& Agle, 2008; Malakyan, 2014).

Recognizing the importance of leader and follower traits, the relationship between leaders and followers, and the context in which leadership is developed, Davies (2009), Haven-Tang and Jones (2012), and Madsen and O’Mullan (2014) argued that the Transformational-Transactional Leadership model was useful for understanding local leadership in rural communities. The TransactionalTransformational model describes two higher order leadership categories. The model, as presented by Bass (1990), facilitates the integration of both transactional and transformational leadership traits and the situation in which the leader-follower relationship is developed (also see Avolio \& Bass, 1999; Bass \& Avolio, 1990, 1993, 1994; Bass \& Riggio, 2006).

Transactional leadership refers to the exchange relationship between leaders and followers to meet their own interests (Avolio \& Bass, 1999; Bass, 1990; Burns, 1978). It was developed from the core tenets of Expectancy Theory of Leadership and the PathGoal Theory of Leadership (Egan, Sarros, \& Santora, 1995). Transformational leadership refers to:

The leader moving the follower beyond imme-
diate self-interests through idealized influence
(charisma), inspiration, intellectual stimulation, or
individualized consideration. It elevates the follow-
er's level of maturity and ideals as well as concerns
for achievement, self-actualization, and the wellbe-
ing of others, the organization, and society. (Davies,
2011, p. 62, first cited in Bass, 1999, p. 11)

Both transactional and transformational leadership have important roles in influencing the outcomes of locally organized community development initiatives (Beer, 2014; Davies, 2009; Haven-Tang 
\& Jones, 2012). Transactional leadership is critical for the ensuring all functional components of a project are completed effectively. However, in cases where the leader is seeking to use a festival or event to bring about broader social and economic change, effective transformational leadership is necessary (Davies, 2007). The remainder of this article examines the nature of leadership as it operated in, and was developed through, the SnowFest festival.

\section{Methods: Documenting Local Leadership Development in Rural Australia}

The data presented and analyzed in this article were collected as part of a larger study that investigated the nature and role of local leadership in rural communities in Australia. The study, conducted over 12 years from June 2002 to June 2014, examined local leadership within six Australian rural communities that had comparable development histories and faced comparable barriers to social and economic viability (see Davies, 2005, for further detail on the selection of case studies). This article reports data that were collected as part of the investigation into leadership in Gloucester, a small agricultural town in inland New South Wales, Australia.

There were five sequential phases of data collection and analysis. The first phase aimed to identify local residents who were leading initiatives that were seeking to improve the social, economic, and/or environmental viability of their town and elicit their perspectives on local leadership. Names of people in leadership roles were identified through a review of websites and print media. All identified potential participants were sent letters requesting interviews and follow-up phone calls were made. For the case being reported, 10 people agreed at this stage to be involved (of a total of 15 who were contacted).

Semistructured interviews were conducted, with participants asked questions about their historical and current involvement in community development initiatives, their leadership philosophy and understanding of leadership traits, opportunities for leadership development and barriers to leadership development, their future intentions in regard to community leadership, and their knowledge about leaders of other community development initiatives. Using a snowballing technique, contact details for other leaders and followers were obtained (Handcock \& Gile, 2011). Letters and phone calls were used to contact those leaders identified through the interviews, and, where the participant was willing, interviews were conducted. As a result of these efforts, two more people were contacted and both agreed to participate.

The second phase of data collection aimed to record the nature of involvement of "followers" in community development initiatives, their views of leadership, and their future intentions in regard to community development initiatives. Followers were identified through the interviews with leaders (Phase One) and also through a review of published documents. For the SnowFest project, seven people participated in these interviews.

The third phase of the study involved developing a preliminary model that explained local leadership and also the identification of leadership traits. The interviews conducted in Phases One and Two were transcribed. An initial thematic analysis was conducted to identify all the leadership traits nominated by participants. A secondary analysis was then conducted to identify the frequency that leadership traits were nominated.

For each leader, their own comments on their leadership style and comments from other leaders and followers about their leadership were thematically analyzed. The various types of relationships between leaders and followers were mapped. Particular focus was given to recording where and how training and mentoring relationships existed. This information was then assessed against existing published information about leadership traits and models. The Transactional-Transformational Leadership model was found to be a useful model for explaining the leader-follower relationship across all cases (Davies, 2005).

Phase Four involved the researcher undertaking follow-up interviews with participants of Phases One and Two. The follow-up interviews were undertaken between 12 and 20 months after the initial interviews. They were less formal in nature, with participants asked to comment on how their involvement in community projects had changed over the period since the first interview, and their future intentions for participation in community leadership roles. Seven leaders from the case study community and all seven of the followers involved in SnowFest participated in these follow-up interviews. 
The final phase of this study involved remotely following the involvement of the interview participants over time in community projects. Through reviewing newspaper articles, occasional circulars, minutes of council meetings, and social media, the researcher identified when leaders and followers became involved in new initiatives and in what capacity.

This study was approved by the University of New England's Ethics Committee. Conditions of the ethics approval included that interview participants were only contacted once during Phase One and once during Phase Two and that further follow-up interviews were not undertaken. The researcher was also obligated to ensure that the confidentiality of participants was maintained in the documenting and reporting of the study results. The following section details the development of local leadership capacities through the SnowFest ${ }^{1}$ festival using the generic descriptors "leader" and "follower."

\section{SnowFest and Local Leadership Development}

\section{Developing Leadership}

SnowFest, first run in 2000, was an annual community-oriented festival, held over a weekend in July. SnowFest was run again in 2001, 2002, and 2003. SnowFest was an initiative of two local community members and was targeted towards generating community support for the development of tourism enterprises in the town. One of the successes of SnowFest was the role it played in shifting community members' attitudes towards the tourism industry. This attitude shift, it is argued, can be attributed to the leadership of the organizers and the subsequent actions of the followers.

Prior to the SnowFest initiative, the case study town, which had a population of 2,300, was fundamentally economically based on the timber, cattle, and dairying industries (Australia Bureau of Statistics, 2013a, 2013b). The town was experiencing social and economic stagnation and population decline. Macroeconomic reforms in agricultural support mechanisms and the national financial regulation system in the 1980s had undermined the economic viability of the dominant agricultural activities in the area (Davies, 2005). Forestry sector reforms, which resulted in large sections of forests within and surrounding the town being classified as National Park or otherwise restricting forestry, together with structural adjustments in the dairy industry in the late 1990s, resulted in considerable job losses, population loss, and financial hardship for residents (Davies, 2005).

Having an economy that was fundamentally structured towards supporting the agricultural and forestry sectors, the decline of the dairying and timber sectors resulted in the closure of numerous businesses. Many of the town's social activities, which had coalesced around its traditional agricultural identity, also suffered decline. The early 2000s, therefore, were characterized by socioeconomic downturn and uncertainty about the future viability of the town. One resident reflected on the period, commenting:

[The town] appeared to be dying. If you went for a drive down the main street you would see lots of vacant stores. ... . There was little prospect for jobs for young and others who were unemployed and so young people were leaving the town in droves. Who can really blame them when even the long time residents were thinking the place was on its last legs. People didn't want to renovate their homes or invest in businesses as they saw there would be little return if the town was going to keep declining.

It is in this context of decline and uncertainty that the SnowFest festival was developed. SnowFest was one of a number of community-led initiatives that were aimed at improving the social and/ or economic viability of the town. Other initiatives were directly concerned with generating new longterm employment opportunities for residents and were organized by the local council. SnowFest, however, developed outside of any existing community group, aimed to highlight the potential of the tourism industry for sustaining future economic and social activities in the town.

Although tourism, particularly nature-based tourism, is now regarded as a crucial part of rural adaptation and growth strategies (Gibson et al., 2011), in the late 1990s it was regarded as a marginal economic function, and one that often did not "fit" with traditional agricultural activities and values (Curry, Koczberski, \& Selwood, 2001). At the time SnowFest was proposed, the fledgling tourism industry was not widely supported by residents. Some viewed the development of the tourism 
industry (which was characterized by ecotourism experiences) as being a threat to the viability of the traditional agricultural and forestry activities of the area.

The SnowFest leaders, who both believed tourism could have a major role in enhancing the economic viability of the town, developed SnowFest as a mechanism to demonstrate to the broader community the potential benefits of developing the region's tourism industry.

The concept of SnowFest was initially proposed at a Shire Council meeting in 2000. The "centerpiece" of SnowFest involved the trucking of snow from the Southern New South Wales snowfields $(750 \mathrm{~km}$ away) and placing this in the center of the town's main street. The snow was to be used by children and adults to play in (this was novel as snow does not naturally fall in the case study town). Interview participants reported that the idea was initially met with strong opposition from some members of the community. Points of opposition were:

- The placing of snow in the town's main street was seen as likely to cause considerable disruption to residents and businesses.

- Investing community resources in developing SnowFest would detract from other efforts that were more closely focused on generating jobs for residents.

- Developing tourism would undermine the already vulnerable agricultural and forestry sectors (see Davies, 2005, for further discussion).

Faced with this initial opposition to the proposal, the two leaders developed a more detailed proposal and implementation strategy for SnowFest. The detailed proposal set out how the event would run in a manner similar to other community events, such as the long running agricultural show. They gained the support of the local chamber of commerce by speaking to members on an individual basis and explaining the merits of the proposal. They then drew on their existing friendship networks and sourced volunteers from the community to assist with organizing of the festival. They secured sponsorship for the event from a local mining company as well as support from other community organizations and the Shire Council. As the support for the event grew, community enthusiasm for the event also grew.
The first SnowFest festival was held on Saturday, July 22, 2000. On the day of SnowFest, 40 tons of snow was piled on the town's main street. Businesses were encouraged to participate by placing scarecrows in the windows of their stores and extending their trading hours (at least eight businesses did). Local and visiting street performers entertained the crowd and local community organizations staffed food and drink stalls (with the proceeds raised going back to the community organizations involved). It was estimated that 8,000 people participated in the event and two thirds of these traveled from outside the locality ("Snow Hits Town," 2000; Tomkinson, 2003).

From the interviews with the leaders and followers it was clear that both leaders and followers recognized that the leaders' transactional leadership was crucial to the success of SnowFest in 2000. Transactional leadership skills underpinned the effective design and management of the event. Both leaders and followers noted that the ability of the leaders to arrange and perform effectively in meetings with members of the Shire, to complete the necessary paperwork for insurance and risk management, and to successfully complete grant applications all were crucial to the success of the event. The seven followers interviewed also agreed that the leaders had good communication and delegation skills, were effective time managers, and were effective financial managers. Importantly, all followers commented that they were provided with the opportunity to develop their own project management skills through their involvement with SnowFest, and all the followers highlighted that one of the leaders had provided all followers with direct support to develop their own transactional leadership capacities.

The followers involved in SnowFest were provided with the opportunity to learn and practice event organization and management skills. Although some followers had previously been involved in organizing community activities, none had previously organized an event as large as SnowFest. Followers reported that through involvement in SnowFest they had become familiar with how to develop and manage relationships with funding partners, how to ensure the effective financial management of an event, strategies for managing the activities of team members (including holding 
regular meetings, minute taking, and the setting of "action" items), strategies for advertising the event, and had gained practical knowledge about working with the Council to arrange street closures, temporary facilities and staff, and insurance for the event.

Given the success of SnowFest in 2000, the organizing committee decided to run the event again in 2001. By the time of the second iteration, both leaders and the followers reported that there was clear evidence that the transactional leadership skills of followers had been developed. To organize the event in 2001, the leaders assembled a team of volunteers. Many had been involved in organizing the 2000 event and reported in the interview that they now felt a sense of "ownership" over it. They reported having confidence in their abilities to not only organize the event but to lead new initiatives to attract and sustain community interest in the event. Two of the followers of the 2000 event recruited new volunteers for the 2001 event and became themselves leaders and mentors to the new recruits. Therefore, an initial outcome from the leadership of SnowFest 2000 was the transference of transactional and transformational leadership skills to others in the town.

Following the 2001 SnowFest, the event leaders recognized that to secure the longer-term future of the event they would require some professional assistance to manage aspects of the event such as securing sponsorship, arranging permissions for road closures and access to public land, and arranging necessary insurance coverage. They identified that the New South Wales Government was running a funding program called the "Townlife Development Fund" and applied for funding for an event administrator. Their application was successful and in 2002 a funded professional event administrator assisted the organization of SnowFest. Although considerable volunteer effort was still required on the day, the event administrator took on a large amount of the work required to organize, fund, and advertise the event.

The event organiser for SnowFest 2002, [involved] many local organisations in the festival so they [could] use the event as a fundraiser for themselves. . . . This has brought us all together with a central focus and will be of benefit for years to come (Tomkinson, 2003).
The 2002 event was successful in terms of maintaining visitor numbers and growing local business participation.

The organizing committee applied to the Townlife Development Fund in 2002 to secure the services of the event administrator for the 2003 SnowFest event. Their application was not successful. A number of members of the organizing committee for the SnowFest events in 2000 and 2001 took on the responsibility for organizing, sourcing funding for, advertising, and managing SnowFest 2003. However, for the 2003 event, the leaders found it more difficult to attract volunteers than in previous years. This was not due to lack of interest in or support for SnowFest, but rather because many of those that had previously been involved in SnowFest were now working on developing new activities and festivals. Others had become involved in establishing or further developing new businesses. Indeed the comments of one of the event leaders indicates the active relationship between the SnowFest organizers and the organizers of other events in the town:

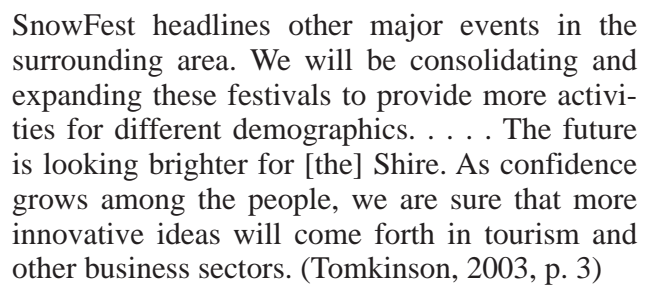

The Phase Two interviews were conducted after the 2003 event as the organizing committee was beginning their discussions for organizing the event in 2004. The 2003 organizing team had found the process of organizing and running the 2003 event substantially more difficult than the 2000 and 2001 events as, with the support of the professional event organizer in 2002, the event had become larger and business and community expectations had increased. Despite the difficulties in organizing the event, over 6,000 people attended in 2003. Of the 2003 event, one participant commented:

We are not sure how this festival got started, but, the crowds are getting larger every year. It is a Fun Filled weekend where the locals welcome one and all to visit this tidy little country town. They Truck in several Semitrailer Coal Truck Loads of SNOW over night from the Snowy Mountains in Southern 
NSW. . . Dump it on the ground in the centre of town, and let the kids or anyone, who has, or, may not have ever been to the Snow fields have some fun. Everyone loves a Snow Fight or Two!!! Up in the main Street there are dozens of Craft stalls \& some entertainment. Plenty of food from street stalls or Local Cafés. IF YOU MISSED GOING THIS YEAR, try \& make the trip next July 2004 (emphasis in the original).

A change in the personal circumstances for one of the leaders resulted in them not remaining involved in the organizing committee for 2004. The remaining members of the organizing committee were uncertain that they could manage the event. Although all followers strongly agreed that they had developed their own leadership and project management skills and had confidence in their abilities to lead community festivals, they felt that SnowFest had become so large and complex they were not confident they could run the event based just on volunteer effort and time. One participant commented, "I was new to this, with new skills ... without the admin support there were just a handful of us doing too much. Time is the main issue."

The festival was "postponed" in 2004. On the decision to postpone SnowFest, the president of the town's Chamber of Commerce commented, "Everyone's keen to run it again, it's just this year we were unable to. . . . There are sound reasons why it isn't running again” (ABC News, 2004, p. 1). Although SnowFest was postponed in 2004 it was not run in 2005 or any year since.

\section{SnowFest's Lasting Legacy of Leadership}

Since SnowFest was first run, the town has transitioned from a declining dairying and forestry community into a vibrant town with a developed tourism industry. In 2014, the town hosted the following events:

- Agricultural and Heritage Show

- Annual Shakespeare Festival

- Motorcycle Expo

- Bull Ride (mechanical bull riding event)

- Mountain Man Tri Challenge

- Wildside Adventure Race (5-day endurance challenge)

- Australian Four Day Enduro (endurance motorbike event)
- Raw Challenge (a 1-day running in the mud event)

- Stock Horse Challenge

- Platypus Festival

- Annual Aero Club Fly-In

- Glorious Garden Ramble

- Buckets of Garlic (food event)

- Monthly Farmers Market

- Weekly Community Market

Due to the conditions of the ethics approval for this study, it is difficult to report precisely on what community development activities followers have become involved in subsequent to their involvement in SnowFest. However, what can be reported is that three of the seven followers interviewed who were involved in SnowFest in 2000, and who also revealed they had no prior experience of leading community development initiatives, had since gone on to lead such initiatives. In the follow-up interviews, these three individuals indicated that they intended to continue to be involved in community development initiatives. Importantly, at the time of the follow-up interviews, they associated their preparedness to be involved in future community development initiatives to their involvement in SnowFest and specifically to the skills and encouragement they had gained from the SnowFest leaders. One participant commented:

Community groups are the essence, the core ... there have been just a few people with bright ideas and the get up and go. Most people just turn up on the day. Now I am more organized. . . . There is a lot still to do. ... I want to work on a hangout for teens, to get attitudes to change, to get people to embrace change.

Another of the followers who was involved in SnowFest but did have prior experience of leading community development initiatives had remained involved in developing and running community festivals and events. In the follow-up interview in 2003, this individual commented that it was through their involvement with SnowFest that their passion for the town had been "reignited" and they were more willing to be involved in community activities. This individual had since gone on to lead six new community development initiatives.

While SnowFest itself did have valuable impacts in terms of attracting visitors and their spending to 
the community, the development of residents' leadership capacities is an important legacy. Although it is not possible to document the exact involvement of the SnowFest followers in community development initiatives since SnowFest, it is revealing that four of the seven followers, who in 2003 attributed their involvement in SnowFest to their leadership skills and intentions to be involved in future community development initiatives, had since taken on leadership roles in the community.

\section{Conclusion: The Legacy of Locally Organized Festivals}

Festivals and events can have lasting impacts on the social and economic activities and viability of host communities. Indeed, for rural communities festivals have become an important strategy for generating new economic activities and community identity. Festivals have long been recognized for their potential to bring increased revenue. However, the broadening of the research scope to examine "beyond economic" and "beyond impact" has revealed that "soft structures" of festivals can generate legacies such as the building of social capital and the enhancement of community identity. Despite the considerable contributions researchers have made to understand the impacts and legacies of festivals, limited attention has been given to examining local leadership. This article aimed to address this gap by reviewing how the locally organized SnowFest acted as a vehicle for the development of local leadership capacities and the legacy of this for the host town.

The SnowFest case highlighted a number of important issues about the development of local leadership capacities. Transformational and transactional leadership were both important in ensuring the success of SnowFest and also to the development of leadership capacities within the community. In SnowFest 2000, the leaders provided interested members of the community with the opportunity to learn and practice the transactional leadership skills that are necessary for the effective organization and running of festivals. Effective transformational leadership enabled the leaders to overcome considerable community opposition to SnowFest. They were able to address residents' concerns and motivate a high level of business and community interest in the event. Seven followers involved in SnowFest identified that they had learned new leadership skills through their involvement in SnowFest and four of these had since taken on leadership roles in the community.

The legacies of events include the planned and unplanned, positive and negative, tangible and intangible structures created for and by the event (Preuss, 2007). Given this definition, identifying the legacies of events is challenging. However, layered on this definition is the acknowledgement that event legacies are not restricted to a particular space or time. Dealing with this challenge, researchers have approached legacy studies by focusing on just one or two soft or hard structures and tracing development of these over a defined period of time and within defined geographic parameters. The examination of the role and nature of leadership in SnowFest used this approach, limiting the time frame to July 2014 and the geographic parameter to the host town. Within these boundaries, it was revealed the particular combination of transactional and transformational leadership employed by the SnowFest leaders resulted in followers gaining leadership skills. Some of these followers had since gone on to lead other community development initiatives.

Although the findings of this study illustrate that the development of local leadership capacities can generate an important legacy of festivals, what remains unclear is the spatial and temporal extent of this legacy. For example, it is unknown how the nature of leadership in SnowFest impacted those not directly involved in organizing SnowFest and the legacy of this. Furthermore, it is unknown to what extent the enhancement of leadership capacities has stimulated other soft or hard structures outside of the case study town or the potential legacies of these.

Although it would be methodologically challenging, future studies could provide crucial insight by examining the broader temporal and spatial dimensions of festival legacies, and also the role of festivals in stimulating and supporting sustainable community development.

\section{Note}

${ }^{1}$ The decision was made to publish the name of the SnowFest festival because the leaders of the festival had published a short article about SnowFest on the NSW 
Community Builders website (archived in 2008) and therefore this information was already available to the public.

\section{References}

ABC News. (2004, March). Hopes melt away for Snowfest. Retrieved January 14, 2015, from http://www. abc.net.au/news/2004-07-05/hopes-melt-away-forsnowfest $/ 2003920$

Arcodia, C., \& Whitford, M. (2006). Festival attendance and the development of social capital. Journal of Convention and Event Tourism, 8(2), 1-18.

Australian Bureau of Statistics. (2013a). 2011 Census of population and housing basic community profile (catalogue number 2001.0) Gloucester 108051167. Retrieved January 14, 2015, from http://www.censusdata.abs.gov.au/cen sus_services/getproduct/census/2011/communityprofile/S SC10981?opendocument\&navpos $=220$

Australian Bureau of Statistics (2013b). 2011 Census of population and housing basic community profile (catalogue number 2001.0) Gloucester UCL 115069. Retrieved January 14, 2015, from http://www.censusdata.abs.gov.au/cen sus_services/getproduct/census/2011/communityprofile/ UCL115069?opendocument\&navpos $=230$

Avolio, B. J., \& Bass, B. M. (1999). Re-examining the components of transformational and transactional leadership using the Multifactor Leadership Questionnaire. Journal of Occupational and Organisational Psychology, 72, 441-462.

Bass, B. M. (1990). From transactional to transformational leadership: Learning to share the vision. Organizational Dynamics, 18, 19-31.

Bass, B. M. (1999). Two decades of research and development in transformational leadership. European Journal of Work and Organisational Psychology, 8, 9-32.

Bass, B. M., \& Avolio, B. J. (1990). Transformational leadership development: Manual for the multifactor leadership questionnaire. Palo Alto, CA: Consulting Psychologist Press.

Bass, B. M., \& Avolio, B. J. (1993). Transformational leadership: A response to critiques. In M. M. Chemmers \& R. Ayman (Eds.), Leadership theory and research: Perspectives and directions (pp. 49-88). Millbrae, CA: Academic Press.

Bass, B. M., \& Avolio, B. J. (1994). Improving organisational effectiveness through transformational leadership. Thousand Oaks, CA: Sage.

Bass, B. M., \& Riggio, R. E. (2006). Transformational leadership (2nd ed.). Mahwah, NJ: Lawrence Erlbaum Associated Inc.

Beer, A. (2014). Leadership and the governance of rural communities. Journal of Rural Studies, 34, 254-262.

Begg, R. (2011). Culturing commitment: Serious leisure and the folk festival experience. In C. Gibson \& J. Connell (Eds.), Festival places: Revitalising rural Australia (pp. 248-264). Bristol, UK: Channel View Publications.

Berridge, G. (2012). The promotion of cycling in London: The impact of the 2007 Tour de France Grand Depart on the image and provision of cycling in the capital. Journal of Sport and Tourism, 17(1), 43-61.

Bob, U., \& Swart, K. (2010). Sport events and social legacies. Alternation, 17(2), 72-95.

Burns, J. M. (1978). Leadership. New York: Harper and Row.

Campbell, S. M., Ward, A. J., Sonnenfeld, J. A., \& Agle, B. (2008). Relational ties that bind: Leader-follower relationship dimensions and charismatic attribution. The Leadership Quarterly, 19, 556-568.

Carlsen, J., Andersson, T. D., Ali-Knight, J., Jeager, K., \& Taylor, R. (2010). Festival management innovation and failure. International Journal of Event and Festival Management, 1(2), 120-131.

Carlsen, J., Ali-Knight, J., \& Robertson, M. (2011). Access: A research agenda for Edinburgh festivals. Event Management, 11, 3-11.

Caust, J. (2002). A festival in disarray: The 2002 Adelaide festival, a debacle or another model of arts organisation and leadership? The Journal of Arts, Management, Law and Society, 34(2), 103-118.

Clifton, N., O’Sullivan, D., \& Pickernell, D. (2012). Capacity building and the contribution of public festivals evaluating “Cardiff 2005.” Event Management, 16, 77-91.

Connell, J., \& Gibson, C. (Eds.). (2011). Festival places: Revitalising rural Australia. Bristol, UK: Channel View Publications.

Crespi-Vallbona, M., \& Richards, G. (2007). The meaning of cultural festivals: Stakeholder perspectives in Catalunya. International Journal of Cultural Policy, 13(1), 103-122.

Curry, G. N., Koczberski, G., \& Selwood, J. (2001). Cashing out, cashing in: Rural change on the south coast of Western Australia. Australian Geographer, 32(1), 109-124.

Darian-Smith, K. (2011). Histories of agricultural shows and rural festivals in Australia. In C. Gibson \& J. Connell (Eds.), Festival places: Revitalising rural Australia (pp. 25-43). Bristol, UK: Channel View Publications.

Davies, A. (2005). Local leadership in rural Australia: The role and nature of local leadership in influencing the socio-economic viability of small agricultural communities. Unpublished doctoral dissertation, University of New England, Armidale, New South Wales.

Davies, A. (2007). Organic or orchestrated: The nature of leadership in rural Australia. Rural Society, 17(2), 139-154.

Davies, A. (2009). Understanding local leadership in building the capacity of rural communities in Australia. Geographical Research, 47(4), 380-389.

Davies, A. (2011). Festival places: Revitalising rural Australia. In C. Gibson \& J. Connell (Eds.), Festival places: Revitalising rural Australia (pp. 61-73). Bristol, UK: Channel View Publications.

Duffy, M., \& Waitt, G. (2011). Rural festivals and processes of belonging. In C. Gibson \& J. Connell (Eds.), Festival places: Revitalising rural Australia (pp. 44-60). Bristol, UK: Channel View Publications. 
Egan, R. F. C., Sarros, J. C., \& Santora, J. C. (1995). Putting transactional and transformational leadership into practice. The Journal of Leadership Studies, 2(3), 100-123.

Fiol, M. C., Harris, D., \& House, R. (1999). Charismatic leadership: Strategies for effecting social change. The Leadership Quarterly, 10(3), 449-482.

Formica, S. (1998). The development of festivals and special events studies. Festival Management \& Event Tourism, 5(3), 131-137.

Getz, D. (2000). Developing a research agenda for the event management field. In J. Allen, R. Harris, L. K. Jago, \& V. J. Veal (Eds.), Events beyond 2000: Setting the agenda. Proceedings of Conference on Event Management (pp. 10-21). Sydney: University of Technology of Sydney.

Getz, D., Andersson, T., \& Carlsen, J. (2010). Festival management studies: Developing a framework and priorities for comparative and cross-cultural research. Festival Management Studies, 1(1), 29-59.

Gibson, C., Connell, J., Waitt, G., \& Walmsley, J. (2011). The extent and significance of rural festivals. In C. Gibson \& J. Connell (Eds.), Festival places: Revitalising rural Australia (pp. 3-24). Bristol, UK: Channel View Publications.

Handcock, M. S., \& Gile, K. J. (2011). Comment: On the concept of snowball sampling. Sociological Methodology, 41(1), 367-371.

Harris, R. (2014). The role of large-scale sporting events in host community education for sustainable development: An exploratory case study of the Sydney 2000 Olympic Games. Event Management, 18(3), 207-230.

Haven-Tang, C., \& Jones, E. (2012). Local leadership for rural tourism development: A case study of Adventa, Monmouthshire, UK. Tourism Management Perspectives, 4, 28-35.

Hede, A., \& Rentschler, R. (2007). Mentoring volunteer festival managers: Evaluation of a pilot scheme in regional Australia. Managing Leisure, 12(2-3), 157-170.

Herbert-Cheshire, L. (2000). Contemporary strategies for rural community development in Australia: A governmentality perspective. Journal of Rural Studies, 16(2), 203-215.

Judge, T.A., Piccolo, R. F., \& Kosalka, T. (2009). The bright and dark sides of the leader traits: A review and theoretical extension of the leader trait paradigm. The Leadership Quarterly, 20(6), 855-875.

Kirkpatrick, S. A., \& Locke, E. A. (1991). Leadership: Do traits matter? The Executive, 5(2), 48-60.

Larson, M. (2011). Innovation and creativity in festival organisations. Journal of Hospitality Marketing and Management, 20(3), 287-310.

Levay, C. (2010). Charismatic leadership in resistance to change. The Leadership Quarterly, 21(1), 127-143.

Li, S., \& McCabe, S. (2013). Measuring the socio-economic legacies of mega-events: Concepts, propositions and indicators. International Journal of Tourism Research, 15, 338-402.

Mackellar, J. (2013). World rally championship 2009: Assessing the community impacts on a rural town in Australia. Sport in Society: Cultures, Commerce, Media, Politics, 16(9), 1149-1163.
Madsen, W., \& O’Mullan, C. (2014). “Knowing me, knowing you": Exploring the effects of a rural leadership programme on community resilience. Rural Society, 23(2), $115-160$.

Mair, J., \& Whitford, M. (2013). An exploration of event research: Event topics, themes and emerging trends. International Journal of Event and Festival Management, 4(1), 6-30.

Malakyan, P. G. (2014). Followership in leadership studies: A case of leader-follower trade approach. Journal of Leadership Studies, 7(4), 6-22.

Moscardo, G. (2007). Analysing the role of festivals and events in regional development. Event Management, 11, 23-32.

Onyx, J., \& Leonard, R. J. (2011). Complex systems leadership in emergent community projects. Community Development Journal, 46(4), 493-510.

Preuss, H. (2007). The conceptualisation and measurement of mega sport event legacies. Journal of Sport and Tourism, 12(3-4), 207-288.

Preuss, H. (2014). Legacy revisited. In J. Grix (Ed.), Leveraging legacies from sports mega-events: Concepts and cases (pp. 24-38). Hampshire, UK: Palgrave Macmillan.

Robertson, M., Rogers, P., \& Leask, A. (2009). Progressing socio-cultural impact evaluation for festivals. Journal of Policy Research in Tourism, Leisure and Events, 1(2), 156-169.

Rollins, R., \& Delamere, T. (2007). Measuring the social impact of festivals. Annals of Tourism Research, 34(3), 805-808.

Sharp, E. K. (2008). Festivals and social change: Intersections of pleasure and politics at a community music festival. Leisure Sciences, 30(3), 217-234.

Small, K., Edwards, D., \& Sheridan, L. (2005). A flexible framework for evaluating the socio-cultural impacts of a (small) festival. International Journal of Event Management Research, 1(1), 66-77.

Snow hits town by the truckload. (2000, July 24). Newcastle Herald, p. 1.

Sorensen, T., \& Epps, R. (1996). Leadership and local development: Dimensions of leadership in four central Queensland towns. Journal of Rural Studies, 12, 113-125.

Tomkinson, L. (2003). Gloucester's story. Sydney, Australia: New South Wales Department of State and Regional Development.

Van Winkle, C. M., \& Woosnam, K. M. (2014). Sense of community and perceptions of festival social impacts. International Journal of Event and Festival Management, 5(1), 22-38.

Wood, E. (2006). Measuring the social impacts of local authority events: A pilot study for a civic pride scale. International Journal of Nonprofit and Voluntary Sector Marketing, 11(3), 165-179.

Zaccaro, S. J., Kemp, C., \& Bader, P. (2004). Leader traits and attributes. In J. Antonakis, A. T. Cianciolo, \& R. J. Sternberg (Eds.), The nature of leadership Thousand Oaks (pp. 101-124). Thousand Oaks, CA: Sage. 